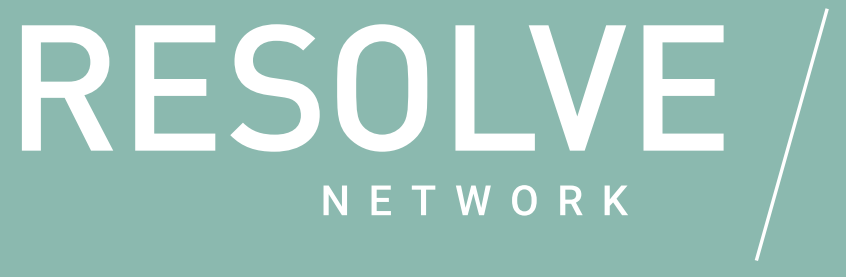

POLICY/NOTE
DECEMBER 2020

https://doi.org/10.37805/pn2020.10.ssa

\title{
STILL KICKING: \\ THE SURVIVABILITY OF THE ISLAMIC STATE \\ IN LIBYA
}

AMANDA B. KADLEC

ISIS IN LIBYA

\section{${ }^{66}$ The apex of ISIS-L's power from 2014 to 2016 may have been brief, and its current threat low, but the group's damage to Libya lingers."}

\section{FAST FACTS Context}

$\rightarrow$ ISIS-L targeted both of the main parties to Libya's civil conflict, the GNA and LAAF. The power struggle between those two parties for foreign patronage leaves little tolerance for ISIS-L's growth.

$\rightarrow$ ISIS-L's foreign roots and backing function as a key impediment to the organization, particularly since its fall from international promi-

nence.

$\rightarrow$ Since its defeat in Sirte and other former strongholds, and in the absence of significant domestic support, ISIS-L has stayed alive by hiding out in remote areas. The group increasingly relies on its neighbors for support.
Within weeks after Libya's civil war reignited in April 2019, the self-proclaimed Islamic State (ISIS) leader Abu Bakr Al-Baghdadi appeared on video for the first time in nearly six years to call followers to Libya's destruction. ${ }^{1}$ Three months later, Mahmud Barassi, one of the country's longtime ISIS leaders, upped the ante by naming it as the new epicenter of ISIS operations. ${ }^{2}$ While these calls failed to manifest a major ISIS resurgence in Libya, they do reflect the organization's lasting ambition to stake a claim in the country and the North Africa's Sahel region at large.

1 Nayera Abdullah Mahmoud, "Islamic State Airs Video Purporting to be Leader Al-Baghdadi," Reuters, April 29, 2020, https://www. reuters.com/article/us-mideast-crisis-baghdadi/islamic-state-airsvideo-purporting-to-be-leader-al-baghdadi-idUSKCN1S51QB.

2 "Activists Say: Terrorist Mahmoud Al Barassi Appeared in the Most Recent ISIS Video," Akhbar Libya, July 9, 2020, https://akhbarlibya24.net/2019/07/09/أغلب-مقاتليه-قتلو|-نشطاء-الإرهابي-مح /2020/. 
Since emerging in eastern Libya in 2014, ISIS Iaid claim to wilayat ${ }^{3}$ within Libya's three regional provinces-Tripolitania, Barqa, and Fezzan-moving fast to establish a quasi-state in the coastal city of Sirte and amassing just a few thousand fighters at its peak strength. ${ }^{4}$ Yet, just as ISIS core's territorial hold in Syria and Iraq withered, its strength in Libya also soon diminished. Sustained domestic and international counterterrorism efforts have severely depleted ISIS in Libya's (ISIS-L) numbers, operational capacity, and opportunity for safe haven.

Since 2017-following its rout from former strongholds in more densely populated areas-ISIS's presence in Libya has been relegated to small cells scattered across the country. The group now numbers only around 100-200 fighters, with concentrations in central Libya around Jufra, Bani Walid, Al-Huruj, Sirte, and sparse southwestern desert areas near Fuqaha, Ghudwa, Zillah, and Murzuq. ${ }^{5}$

ISIS-L remains a shadow of its former self, unable to hold territory or establish a stronghold. The emaciated group with its limited ideological influence is reduced to staging disparate and intermittent attacks in rural and urban settings. Nevertheless, it boasts about its nighttime raids in dramatic, glossy video clips that overstate the organization's capacity. ${ }^{6}$

Observers warned that the resumption of violent civil conflict in 2019 handed the organization yet another opportunity to exploit the country's chaos and to reclaim its footing. ${ }^{7}$ Indeed, the instability intrinsic to the ongoing competition - the eastern-based armed coalition led by Khalifa Haftar, known as the Libyan Arab Armed Forces (LAAF) ${ }^{8}$ pitted against the western-based armed groups affiliated with the Tripoli Government of National Accord (GNA) ${ }^{9}$-contributes to ISISL's survival. Both factions are composed of a loose assortment of armed groups ranging from a handful of well-trained professional special operations brigades, to criminal gangs and ragtag volunteer fighters, all of which often clash with one another. Neither party to the nationwide conflict has been able dismantle ISIS-L on its own and neither is spared by ISIS-L's attacks. ${ }^{10}$

3 Administrative division, province, territorial governorate.

4 Estimates of Islamic State fighters in Libya during the 2015-2016 timeframe have varied widely depending on the source. The author considered figures from open sources and author interviews as the basis for this estimate.

5 United Nations Security Council, Final Report of the Panel of Experts on Libya established pursuant to Security Council Resolution 1973 (2011), S/2019/914, December 9, 2019, https://undocs.org/S/2019/914.

6 Inga Kristina Trauthig, "Islamic State in Libya: From Force to Farce?," International Centre for the Study of Radicalisation, King's College London, March 10, 2020, https://icsr.info/wp-content/uploads/2020/03/ICSR-Report-Islamic-State-in-LibyaFrom-Force-to-Farce.pdf.

7 Emily Estelle, "Al Qaeda and the Islamic State will be the Winners of the Libyan Civil War," Critical Threats Project, American Enterprise Institute (AEI), April 10, 2019, https://www.criticalthreats.org/analysis/ al-qaeda-and-the-islamic-state-will-be-the-winners-of-the-libyan-civil-war.

8 Khalifa Haftar launched the 2014 offensive known as Operation Karama under what he termed the Libyan National Army (LNA), a loose coalition of armed groups and tribal support. The force was renamed in 2018 as the Libyan Arab Armed Forces (LAAF).

9 Forces affiliated with the GNA since 2016 are based primarily in Tripoli and environs, Misrata, Zawiya, and Zintan. These armed groups, although aligned against the LAAF, are routinely also in conflict with one another.

10 Following the LAAF's withdrawal from Tripoli and surrounding areas, ISIS-L attacks halted. See: United States Department of Defense, North and West Africa Counterterrorism Operation, Lead Inspector General Report to the United States Congress, July 1, 2020 - September 30, 2020, https://media.defense.gov/2020/Nov/25/2002541626/-1/-1/1/LEAD\%20IG\%20EAST\%20 AFRICA\%20AND\%20NORTH\%20AND\%20WEST\%20AFRICA\%20COUNTERTERRORISM\%200PERATIONS.PDF 
However, while weakened, ISIS-L's survivability is driven by a far more complex range of factors than just Libya's domestic unrest. The apex of ISIS-L's power from 2014 to 2016 may have been brief, and its current threat low, but the group's damage to Libya lingers, and the potential for its continued periodic revival should not be understated.

\section{Relevance to policy and practice}

The battle against ISIS-L-and the group's cooperation with al-Qaeda-linked elements that ultimately permitted its initial land seizures and territorial establishment-coincided with critical periods in Libya's political transition. More than just a series of destabilizing, standalone events, the sounding alarms regarding ISIS-L's presence distracted successive governments from post-revolution reconciliation and state-building. As the goal of eradicating ISIS-L monopolized international and domestic security attention, it directed focus away from broader stabilization plans and, in doing so, irreparably derailed Libya's state-building momentum. ${ }^{11}$

The efforts of a half dozen foreign governments to buttress domestic actors affiliated either with Haftar or the Tripoli government-and in some cases both-often under counterterrorism auspices, has factored considerably into the endless cycle of domestic strife in Libya upon which ISIS is known to thrive. These insertions indirectly encouraged parties on both sides of the conflict to claim an "anti-ISIS" mantle and the international legitimization it affords. ${ }^{12}$ Today, the powers still directly invested in the outcome of conflict in Libya-Russia, France, Qatar, Italy, Egypt, the United Arab Emirates, Turkey, Jordan, the United Kingdom, and the United States-maintain support to the different sides in a conflict that at this stage only marginally involves fighting terrorist organizations.

In a set of dynamics that is perhaps unique to the country, Libya's nationwide political conflict has proven to be both a cause of and an impediment to the organization's endurance. The organization repeatedly demonstrates the adaptability to resurface with lethality, despite the array of factors constraining its expansion. Yet, every strength ISIS-L presents is countered by multidimensional domestic resistance factors on both sides of the civil conflict. While ISIS-L numbers and capacity remain limited, the style of operation and target will adapt as Libya's civil conflict evolves both in complexity and international dimension. For those seeking to counter and addresS ISIS-L'S continued presence in Libya, understanding the factors that simultaneously facilitate and hamper the group's operations and growth is paramount to crafting appropriate interventions.

11 Amanda Kadlec, "All Eyes on Sirte: Beating the Islamic State, but Loosing Libya," War on the Rocks, June 23, 2016, https:// warontherocks.com/2016/06/all-eyes-on-sirte-beating-the-islamic-state-but-losing-libya/.

12 Permanent Mission of France to the United Nations, "France is in Libya to Combat Terrorism," February 24, 2020, https:// onu.delegfrance.org/Jean-Yves-Le-Drian-France-is-in-Libya-to-combat-terrorism-By-Isabelle-Lasserre; Arab Weekly, "Priority in Libya is to Counter Terrorism, says U.A.E.," Arab Weekly, May 29, 2019, https://thearabweekly.com/priority-libya-counterterrorism-says-uae; Carla Babb, "Third US Strike in Libya Targets Islamic State Terror Group," September 27, 2019, https:// www.voanews.com/africa/third-us-strike-libya-targets-islamic-state-terror-group. 


\section{Key Considerations}

\section{ISIS-L in the Libyan conflict: a common enemy and a source of competition}

ISIS-L clearly does not play favorites when making enemies. Since it lost land and administrative control of populated urban areas to GNA-allied armed groups, ISIS-L has launched successive, intermittent, small scale attacks on targets within those areas. Offensives on attention-grabbing GNA institutions and people-government ministries, critical infrastructure, checkpoints, and local officials - continue to exacerbate Libya's post-revolution instability and demonstrate ISISL's capacity to maneuver even in locations where well-trained and equipped counterterrorism forces are based. Deadly assaults throughout 2017 and $2018^{13}$ sent clear messages that ISIS-L will continue its attempts to disable the GNA's management of the state.

This dynamic, however, changed after the onset of the civil conflict last year. ISIS-L shifted its operations and began targeting LAAF with conspicuous frequency, ${ }^{14}$ which has led to oft-repeated accusations on social media that armed groups affiliated with the GNA collaborate with ISIS-L elements. ${ }^{15}$ In one among several anti-LAAF incidents last year, ISIS-L launched an attack on an army training camp in LAAF-controlled Sabha in May, killing nine. ${ }^{16}$

While the anarchic conditions in Libya certainly provide ISIS-L the space to continue to operate, its reach is for the moment still checked. ISIS-L targeted both of the main parties to Libya's civil conflict, the GNA and LAAF. The power struggle between those two parties for foreign patronage leaves little tolerance for ISIS-L's growth. Even the perception of closeness with ISIS-L, through rumors or accusations, damages image locally and internationally-an unacceptable premise if the GNA's foreign backing under the remit of counterterrorism operations is to be maintained. Competition to earn this credibility as the singular anti-ISIS force has been fierce, but neither side, despite seemingly earnest efforts and boundless foreign support, is able to control ISIS-L.

\section{ISIS-L's foreign roots: local support and local resistance}

Since the early days of ISIS's foothold in Libya amid the onset of civil war in 2014, top ISIS-L leadership was considerably non-native. ISIS-L's first and subsequent emirs were Iraqi nationals Wissam Al Zubaydi (aka Abul Mughirah al-Qahtani and Abu Nabil Al Anbari) and Abu Mu'az al-

13 Attack targets throughout 2017 and 2018 include state institutions managed by the GNA: Libya's Ministry of Foreign Affairs, the High National Electoral Commission, the National Oil Corporation in the capital, and a court complex in Misrata, Libya's third largest city.

United States Department of State, Country Reports on Terrorism: 2019, Bureau of Counterterrorism, https://www.state.gov/ reports/country-reports-on-terrorism-2019/Libya/.

Jacqueline Lacroix, "Social Media and Conflict in Libya: A Lexicon of Hate Speech Terms," Peace Tech Lab, June 19, 2019, https://static1.squarespace.com/static/54257189e4b0ac0d5fca1566/t/5d0a6faf6246f7000131b90b/156096508.

16 Ayman al-Warfalli and Ahmed Elumami, "Nine soldiers killed in south Libya attack on Haftar camp: hospital," Reuters, May 4, 2019, https://www.reuters.com/article/us-libya-security-sebha-idUSKCN1SA08E. 
Tikriti ${ }^{17}$ (aka Abdul Qader Nadji), sent to Libya by Baghdadi in 2014. ${ }^{18}$ This connection to ISIS core laid the groundwork for expansion in Libya, providing financing, a hierarchical structure, leadership support, and a ready supply of fighters.

While the founding of ISIS-L was led by outsiders, the organization found safe haven in coexistence with other Libyan Salafi jihadist armed groups and individuals. The group's ability to attract Libyan allies-including, in some instances, armed groups seeking alliance in opposition to Haftar rather than for ideological reasons-facilitated ISIS-L's capacity to expand in its early days. For example, ISIS-L cooperated with the Benghazi Revolutionary Shura Council (BRSC) and Ansar al-Sharia, both linked to al-Qaeda ( $\mathrm{AQ}$ ), and unaffiliated Misrata-originated armed groups in opposition to Khalifa Haftar, their common enemy, in 2014. ${ }^{19}$ Meanwhile, Mahmoud al-Barassi, a key leader in the organization since its origins in Benghazi, is likely a native of the country's eastern tribal base. ${ }^{20}$ Similarly, Malik Khazmi-a prominent ISIS-L recruiter suspected to have radicalized the Manchester bomber Salman Abedi while he was in Libya-is a native of the central Libyan town of Bani Walid. ${ }^{21}$

That ISIS has never been uniquely Libyan-yet composed of just enough Libyans to gain localized foothold-enabled the group to operate. Support from ISIS core ensured the group was adequately resourced and supported. Concurrent support from the few Libyans for whom the ISIS call resonated provided just enough cultural and domestic conflict knowledge to ground the organization's aspirations and exploit Libya's inherent weaknesses.

At the same time, ISIS-L's foreign roots and backing also function as a key impediment to the organization, particularly since its fall from international prominence. All politics in Libya is hyperlocal, an environment where ISIS-L tactics of domination over tribal identities and localized groups-compared to longer-term co-optation and integration methods of $A Q$-is met with considerably more resistance. The ISIS-L narrative in Libya is moreover superseded by the country'S non-jihadist brand of Salafism of the Madkhali that aligned with political-military forces opposed to it. Armed groups identifying with the revolutionary narrative opposed to the Qaddafi regime also consider ISIS and the foreign fighters it relies on as unwelcome foreign imports. Several hundred GNA-aligned fighters laying claim to this narrative died in the 2016 battle back by the US and the UK that drove ISIS-L out of Sirte, and would loathe to see ISIS-L's revival.

17 The LAAFclaimed to havetargeted and killed Tikriti in September 2020. U.S.governmentagencies madenostatements oftheevent at the time. See: Reuters Staff, “Eastern Libya Forces Say They Killed Islamic State Leader," Reuters, September 23, 2020, https:// www.reuters.com/article/us-libya-security/eastern-libyan-forces-say-they-killed-islamic-state-leader-idUSKCN26E3BW. Anbari and Qahtani were killed in USAFRICOM airstrikes, in 2015 and 2018 respectively. See: Tom Smith and Hussein Solomon, Exporting Jihad - Volume I: Critical Perspectives from Africa and Europe (London: Bloomsbury Press, 2020$) 129$.

19 Tim Eaton, Abdurahman al Ageli, et al., "The Development of Libya's Armed Groups Since 2014: Community Dynamics and Economic Interests," Chatham House, March 2020, https://www.chathamhouse.org/publication/ development-libyan-armed-groups-2014-community-dynamics-and-economic-interests.

20 Tribal name Barassa is native to eastern Libya. His alias is Abu Musab al-Libi (Abu Musab "the Libyan”).

21 Among several ISIS-L leaders have been reportedly killed in prolific US AFRICOM airstrikes over the past six years. See: Sudarsan Raghavan, "Libya's civil war creates opening for ISIS return as counterterrorism effort falters," Washington Post, November 24, 2019, https://www.washingtonpost.com/world/middle east/libyas-civil-war-creates-opening-for-isis-return-as-counterterrorism-effort-falters/2019/11/21/e78745c0-056c-11ea-9118-25d6bd37dfb1 story.html. 
Strategies for countering ISIS in Libya and the Sahel, therefore, must be made with comprehensive consideration for the complexities within Libya and with regard to the foreign actors involved in the conflict.

\section{ISIS-L's regional ties: supply sources and local longevity}

Since its defeat in Sirte and other former strongholds, and in the absence of significant domestic support, ISIS-L has stayed alive by hiding out in remote areas, drawing attention to itself in short bursts. In this context, the group also increasingly relies on its neighbors for support. Libya is situated in a region where ISIS affiliates in the Sahel and West Africa have gained considerable ground in recent years, providing a backdrop for operations across the Malian and Nigerien borders. ${ }^{22}$ In this context, where ISIS and AQ are also known to collaborate, ISIS-L is able to draw income from smuggling throughout the southwest of Libya through its regional connections. ${ }^{23}$

West African and Sahelian-origin recruits comprise a considerable part of ISIS-L composition. The proximity of ISIS-L to affiliates just to Libya's south, and to further countries such as Burkina Faso, provide opportunities to replace fighters lost by Libyan and international counterterrorism operations, as well as opportunities for greater regional cooperation. ISIS-L today most certainly also includes Libyan-born fighters, however limited, as is necessary to sustain the local relationships required to negotiate and maintain its physical presence and revenue streams-including its well-established role in Libya's prolific black market. Trade in antiquities looted from the Levant, localized extortion, and protection for smugglers and traffickers through the Sahel ensure a steady, difficult to pinpoint stream of income that will render ISIS-L's presence and destabilizing impact a long-term phenomenon. ${ }^{24}$

Complicating matters further, Libya's array of armed groups of varied tribal affiliation, loyalty, and economic interest that are involved in illicit trade make the identification of those that do cooperate with ISIS-L that much harder. These ambiguous links among multiple groups and individuals involved in various trafficking activities across borders by air, sea, and land are central to the survival of ISIS-L's currently limited numbers. For instance, Musa Adyab, a notorious human trafficker from Bani Walid, at one point maintained unfettered passage of migrants through "taxation" payments to ISIS-L, as well as with AQ-linked, Salafi, and other unaffiliated brigades. ${ }^{25}$ Given its engagement in local and regional illicit supply chains, the presence of ISIS in Libya, therefore, cannot be addressed in isolation, by air strikes alone. A simultaneous dismantling of complex domestic and international support networks is also required.

22 Jason Warner and Charlotte Hulme, "The Islamic State in Africa," Estimating Fighter Cells Across the Continent," CTC Sentinel 11, nr. 7 (August 2018) https://ctc.usma.edu/islamic-state-africa-estimating-fighter-numbers-cells-across-continent/.

23 Carley Patesch, "Al Qaeda, ISIS affiliates team up in West Africa, says US Special Operations Command Africa Leader," Military Times, February 27, 2020, https://www.militarytimes.com/news/your-military/2020/02/27/ al-qaida-isis-affiliates-team-up-in-west-africa-says-us-special-operations-command-africa-leader/.

24 United Nations Security Council, Twenty-fourth report of the Analytical Support and Sanctions Monitoring Team submitted pursuant to resolution 2368 (2017) concerning ISIL (Da'esh), Al-Qaida and associated individuals and entities, S/2019/570: 9, July 15, 2019, https://undocs.org/S/2019/570.

25 Abyad was designated by the UN in 2018 for his trafficking activities. A counterterrorism operation to capture him in 2019 failed, arrest warrant still standing. 


\section{Conclusion}

While many factors enabled ISIS-L to take root in Libya, those same factors, in many cases, have also stymied its operations, efforts, and diminished its presence in the country. Resistance by local populations-in some cases supported by well-armed, trained, and externally financed militia groups-curtailed the largely foreign-rooted organization's spread. While the country's instability amid transition enabled ISIS-L to initially take root and later reemerge in Libya, the current conflict has also deterred ISIS-L's growth. As Libya's armed groups fight a war over political power and state resources backed by sustained international support for anti-ISIS efforts, few have reason or potential gain by aligning with it outright. Today, a year and a half after Haftar launched his April 2019 offensive to capture Tripoli, ISIS-L remains scattered and operationally stymied.

Additionally concerning is that ISIS affiliates throughout the Sahel region are not only present, but expanding in Libya's backyard where the French-led and US-supported G5 Sahel initiative to curtail it is falling short. ${ }^{26}$ ISIS-L's intermittent cooperation with AQ-with its long history and established relationships throughout North Africa and engagement in illicit trade and financing activities-augments opportunities for ISIS to resurface in Libya time and time again depending on the circumstances of domestic conflict.

The U.S. and its allies have taken a narrow approach to countering ISIS in Libya without fully accounting for the complexities embedded within the domestic conflict or those of the Sahel region at large. Airstrikes on targets in Libya's desert and troop presence in neighboring countries are without doubt effective at decimating the organization's operational capacity, but the results are short-term. The civil conflict that resurged in 2019 may not have resulted in a concrete win for ISIS-L. However, unless and until Libya's internal strife is resolved-and clearer distinctions are drawn regarding the level of cooperation between ISIS-L and Libya's other armed groups currently fighting under either of the national banners-domestic and international policies to stifle the organization will fall flat in the years to come.

26 Andrew Lebovich, "Insecurity in the Sahel: Europe's Next Fight Against Jihadism," European Council on Foreign Relations, February 5, 2020. https://www.ecfr.eu/article/commentary insecurity in the sahel europes next fight against jihadism 


\section{Suggested Further Reading}

\section{Islamic State in Libya}

Azeem, Ibrahim. "Rise and Fall? The Rise and Fall of ISIS in Libya." Carlisle, PA: United States Army War College Press, 2020. https://press.armywarcollege.edu/monographs/913.

Beccaro, Andrea. "ISIS in Libya and Beyond: 2014-2016." The Journal of North African Studies, March 29, 2020. https://doi.org/10.1080/13629387.2020.1747445.

Gonel, Tuba. "State Capacity and Political Violence: The Case of ISIS and Libya." Master's Thesis, Sabanci University, 2018. https://www.semanticscholar.org/paper/State-capacity-andpolitical-violence\%3A-the-case-of-Gönel/749e295cec2b924a1d4821981269aa5f1465 $\underline{\mathrm{e} 2 \mathrm{e} 5}$

\section{Islamic State in Africa}

Foucher, Vincent. "The Islamic State Franchises in Africa: Lessons from Lake Chad." International Crisis Group, Commentary, October 29, 2020. https://d2071andvip0wj.cloudfront.net/iswap-29oct20.pdf

International Crisis Group. "How the Islamic State Rose, Fell and Could Rise Again in the Maghreb." International Crisis Group No. 178, July 24, 2017. https://www.crisisgroup.org/middle-east-north-africa/ north-africa/178-how-islamic-state-rose-fell-and-could-rise-again-maghreb.

Nasir, Wassim. "ISIS in Africa: The End of the 'Sahel Exception."” Center for Global Policy, June 2, 2020. https://cgpolicy.org/articles/isis-in-africa-the-end-of-the-sahel-exception/

Thurston, Alexander. Jihadists of North Africa and the Sahel: Local Politics and Rebel Groups. Cambridge: Cambridge University Press, 2020. https://doi.org/10.1017/9781108771160

\section{Sources}

Akhbar Libya. "Activists Say: Terrorist Mahmoud Al Barassi Appeared in the Most Recent ISIS Video." Akhbar

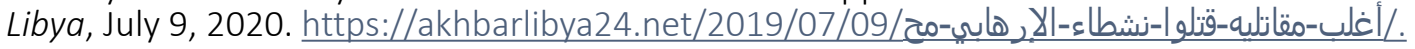

Arab Weekly. "Priority in Libya is to Counter Terrorism, says U.A.E." Arab Weekly, May 29, 2019. https:// thearabweekly.com/priority-libya-counter-terrorism-says-uae.

Babb, Carla. "Third US Strike in Libya Targets Islamic State Terror Group." September 27, 2019. https:// www.voanews.com/africa/third-us-strike-libya-targets-islamic-state-terror-group

Eaton, Tim, Abdurahman al Ageli, et al. "The Development of Libya's Armed Groups Since 2014: Community Dynamics and Economic Interests." Chatham House, March 2020, https://www.chathamhouse.org/ publication/development-libyan-armed-groups-2014-community-dynamics-and-economic-interests.

Estelle, Emily. "Al Qaeda and the Islamic State will be the Winners of the Libyan Civil War." Critical Threats Project, American Enterprise Institute (AEI), April 10, 2019. https://www.criticalthreats.org/analysis/ al-qaeda-and-the-islamic-state-will-be-the-winners-of-the-libyan-civil-war.

Kadlec, Amanda. "All EyesonSirte: Beating the IslamicState, but Loosing Libya." Waronthe Rocks, June23, 2016. https://warontherocks.com/2016/06/all-eyes-on-sirte-beating-the-islamic-state-but-losing-libya/ 
Lacroix, Jacqueline. "Social Media and Conflict in Libya: A Lexicon of Hate Speech Terms." Peace Tech Lab, June 19, 2019. https://static1.squarespace.com/static/54257189e4b0ac0d5fca1566/t/5d0a6faf6246f $7000131 \mathrm{~b} 90 \mathrm{~b} / 156096508$.

Lebovich, Andrew. "Insecurity in the Sahel: Europe's Next Fight Against Jihadism." European Council on Foreign Relations, February 5, 2020. https://www.ecfr.eu/article/ commentary insecurity in the sahel europes next fight against jihadism

Mahmoud, Nayera Abdullah. "Islamic State Airs Video Purporting to be Leader Al-Baghdadi." Reuters, April 29. 2020. https://www.reuters.com/article/us-mideast-crisis-baghdadi/ islamic-state-airs-video-purporting-to-be-leader-al-baghdadi-idUSKCN1S51QB.

Patesch, Carley. "AI Qaeda, ISIS affiliates team up in West Africa, says US Special Operations Command Africa Leader." Military Times, February 27, 2020. https://www.militarytimes.com/news/your-military/2020/02/27/al-qaida-isis-affiliates-team-up-in-west-africa-says-us-special-operations-commandafrica-leader/

Permanent Mission of France to the United Nations. "France is in Libya to Combat Terrorism." February 24, 2020. https://onu.delegfrance.org/Jean-Yves-Le-Drian-France-is-in-Libya-to-combat-terrorism-ByIsabelle-Lasserre.

Raghavan, Sudarsan. "Libya's civil war creates opening for ISIS return as counterterrorism effort falters." Washington Post, November 24, 2019. https://www.washingtonpost.com/world/middle east/libyascivil-war-creates-opening-for-isis-return-as-counterterrorism-effort-falters/2019/11/21/e78745c0056c-11ea-9118-25d6bd37dfb1 story.html.

Reuters Staff. "Eastern Libya Forces Say They Killed Islamic State Leader." Reuters, September 23, 2020. https://www.reuters.com/article/us-libya-security/eastern-libyan-forces-say-they-killed-islamic-stateleader-idUSKCN26E3BW

Smith, Tom, and Hussein Solomon. Exporting Jihad - Volume I: Critical Perspectives from Africa and Europe. London: Bloomsbury Press, 2020.

Trauthig, Inga Kristina. "Islamic State in Libya: From Force to Farce?" International Centre for the Study of Radicalisation, King's College London, March 10, 2020, 17. https://icsr.info/wp-content/uploads/2020/03/ ICSR-Report-Islamic-State-in-Libya-From-Force-to-Farce.pdf.

United Nations Security Council. Twenty-fourth report of the Analytical Support and Sanctions Monitoring Team submitted pursuant to resolution 2368 (2017) concerning ISIL (Da'esh), Al-Qaida and associated individuals and entities. S/2019/570: 9, July 15, 2019. https://undocs.org/S/2019/570.

United Nations Security Council. Final Report of the Panel of Experts on Libya established pursuant to Security Council Resolution 1973 (2011). S/2019/914, December 9, 2019. https://undocs.org/S/2019/914.

United States Department of Defense. North and West Africa Counterterrorism Operation. Lead Inspector General Report to the United States Congress, July 1, 2020-September 30, 2020. https://media. defense.gov/2020/Nov/25/2002541626/-1/-1/1/LEAD\%20IG\%20EAST\%20AFRICA\%20AND\%20 NORTH\%20AND\%20WEST\%20AFRICA\%20COUNTERTERRORISM\%20OPERATIONS.PDF

United States Department of State. Country Reports on Terrorism: 2019. Bureau of Counterterrorism. https://www.state.gov/reports/country-reports-on-terrorism-2019/Libya/.

al-Warfalli, Ayman, and Ahmed Elumami. "Nine soldiers killed in south Libya attack on Haftar camp: hospital." Reuters, May 4, 2019. https://www.reuters.com/article/us-libya-security-sebha-idUSKCN1SA08E

Warner, Jason, and Charlotte Hulme. "The Islamic State in Africa: Estimating Fighter Cells Across the Continent." CTC Sentinel 11, nr. 7 (August 2018) https://ctc.usma.edu/ islamic-state-africa-estimating-fighter-numbers-cells-across-continent/. 


\section{About the Note}

Author: Amanda Brooke Kadlec

Amanda Brooke Kadlec is a Middle East North Africa policy researcher and consultant specializing in security and political governance in conflict and transitioning states. Amanda is a Fulbright fellow, former RAND analyst, and armed groups expert for the United Nations Security Council Panel of Experts (2019-2020).

The views expressed in this publication are those of the authors. They do not necessarily reflect the views of the RESOLVE Network, the U.S. Institute of Peace, or any entity of the U.S. government.

\section{RESOLVE NETWORK}

better research.informed practice.improved policy on violent extremism.

www.resolvenet.org

y $f$ in 